\title{
THE ANTIQUITY OF CAESAREAN SEGTION WITH MATERNAL SURVIVAL: THE JEWISH TRADITION
}

by

\section{JEFFREY BOSS}

THE operation of caesarean section is performed for two purposes: to rescue a living infant from a moribund or recently dead mother, and to rescue alive both mother and child from a difficult or prolonged labour. As to the first, the Lex Regis of Numa Pompilia (715-672 B.c.) states: 'Negat lex regia mulierem quae pregnans mortua sit, humari, antequam partus ei excidatur: qui contra fecerit, spem animantis cum gravida peremisse videtur.' ('The lex regia forbids the burial of a pregnant woman before the young has been excised: who does otherwise clearly causes the promise of life to perish with the mother.') The earliest recorded application of the law is from about 500 B.c. ${ }^{2}$ Although this rescuing of the infant from its dead mother is not mentioned in the writings of Hippocrates, Avicenna, Gelsus, Paulus Aegineta ${ }^{3}$ or in the Mosaic code, ${ }^{4}$ it was widely practised in ancient times not only by the Romans but by Indians in Vedic times ${ }^{4}$ and by Jews in the Roman period. ${ }^{5}$

The excision of a living child from the belly of a woman reasonably expected to survive is known to us in circumstances of four kinds: (a) In our Western tradition of surgical practice, the operation has been performed for four hundred years and is now a useful and safe technique. (b) Isolated examples of women who have recovered after delivering themselves by caesarean section have been reported from Europe, North America and Africa. ${ }^{6,} 7$ Ploss ${ }^{7}$ reports the operation on a Chippewa woman by her husband. (c) Felkin, ${ }^{8}$ in 1884, reported the delivery by caesarean section of a Bunyoro woman of Uganda. The technique implied a well-developed tradition, and Davies ${ }^{9}$ has recently argued cogently that Felkin's account could not have been fictitious. $(d)$ There are indications that, during the Roman period, it was common among the Jews, for a mother to recover from a caesarean section. The evidence is contained in rabbinical reports, dating from the second century A.D., of verbal discussions which took place rather earlier. These discussions suggest that there was already a long-standing tradition of practice at the operation. Hitherto it has commonly been concluded or assumed that there is no sound evidence for caesarean section with maternal survival before 1500 A.D. If, however, the rabbinical reports are accepted as implying familiarity with the mother's recovery from the operation, the date for the earliest practice of caesarean section with a successful outcome for both mother and child must be advanced by almost a millennium and a half. 


\section{Jeffrey Boss}

This paper, therefore, is a critical analysis of rabbinical, principally Talmudic, evidence that the Jews in Roman times were already familiar with caesarean section of the living mother, performed in the normal expectation of her survival. The Hebrew technical term is yotsé dofan. Yotsé is the present participle of the verb 'go out' and dofan is the 'body-wall'; yotsé dofan is thus, literally, 'an emerger of the parietes', that is, one born through the body-wall. A common translation is 'one who comes forth from the side' as in Surenhusius's translation $^{10}$ of the Mishnah, qui e latere prodiit (Bekhorot ii, 9); whether dofan is to be translated as 'side' in phrases such as this will be discussed below. The task undertaken here is to examine evidence that a yotsé dofan could have a surviving mother.

\section{Previous Discussion}

During the course of this investigation it became apparent that much of the ground had been covered by previous workers, especially A. H. Israels.11 Mansfeld, ${ }^{12}$ in 1824 , suggested that the Talmud referred to caesarean section of living patients, but regarded the discussions as fantasies on theoretical possibilities; the mediaeval 'thought-experiments's ${ }^{13}$ provide a parallel, perhaps, to what Mansfeld had in mind. Fulda, ${ }^{14}$ two years later, contradicted Mansfeld, denying the possibility even of fantasies. Von Siebold, ${ }^{15}$ in 1845 , quoted Mansfeld without comment, and in the same year Israels' monograph ${ }^{11}$ was published.

The discussion by Israels is very thorough and is obviously based on a wide reading of the Talmud. Fulda is answered in detail, and a strong case is made out for the performing of ante-mortem caesarean section in the early centuries of the Christian era. In view of this excellent monograph, it would be unnecessary to re-open the discussion, were it not that Israels' monograph is now hard to obtain, that his conclusions are not yet generally accepted and that the discussion to be presented in this paper encompasses some material not used by Israels.

Reich, ${ }^{16}$ in 1866 , argued that the Talmudic rabbis were familiar with antemortem caesarean section. He mentions passages not considered by Israels, but it is only the material already used by the latter which is immediately relevant in attempting to determine whether the operation was successfully performed. Schapiro ${ }^{17}$ took the matter further, discussing the technique itself; his examination of Talmudic obstetrics indicates considerable surgical skill among Jews of the Roman era.

In the last half-century there appears to have been no fresh contribution to this discussion. Fasbender's Geschichte der Geburtshülfe $e^{4}$ ignores caesarean section among the Jews, while Neuburger's History of Medicine ${ }^{18}$ refers to the subject, but adds nothing and is non-committal in its conclusions. I have been able to find nothing on this topic in the works of Charles Joseph Singer. Pickrell's paper $^{3}$ on the history of caesarean section is concerned principally with the period since 1500 A.D., but he quotes, at second-hand, two of the relevant Talmudic passages, including them in that part of the subject derived from I 18 


\section{The Antiquity of Caesarean Section with Maternal Survival: the Fewish Tradition}

'myths, legends and other non-medical sources'. Ploss' reviews the subject and quotes Julius Fürst, who states that yotsé dofan is a 'flank delivery' and not an 'abdominal section' and that 'it is natural that the ancient Hebrews, who were, in scientific knowledge, quite dependent on the surrounding civilized nations, might not have known such an operation'. Fürst's statement, of course, begs the question under examination, and is quoted here only to illustrate the kind of muddled thinking which prevents our detecting ability or achievement where previously formed historical generalizations have led us not to expect them. Young's history of caesarean section ${ }^{6}$ refers to the possibility that the Jews practised ante-mortem caesarean section in the Roman period, but adds nothing to the earlier reviews on this topic.

\section{Textual Material}

The teaching of the rabbis in the last two centuries before Christ and the first two of the Christian era are gathered into two main collections, the Mishnah and Tosefta. The Tosefta contains material omitted from the Mishnah, but of comparable origin. The teachers of this period, the Tannaim, were succeeded by the Amoraim, whose discussions on the Mishnah down to about 450 A.D. were collected into the Gemara, Mishnah and Gemara together forming the Talmud. As there are two Gemaras, one Mesopotamian and one Palestinian, there are two Talmuds, the Babylonian and the Jerusalmi, the former often called 'Talmud' without qualification. Within the Gemaras is embedded Tannaitic teaching; such outlying items from the Tannaitic period are termed baraitas, which are also found in the rabbinical commentaries on books of the Bible. In general, the Mishnah, Tosefta and earliest biblical commentaries are in Hebrew, the Gemaras in Aramaic.

In order to assess the historical worth of a saying attributed to the Tannaim, it is necessary to consider the conditions under which our information was recorded and transmitted. The rabbis of the Mishnaic period did not commit their views to writing, and it was possibly only in the second century A.D., after the failure of Bar-Cochba's revolt, that their teachings were gathered into written collections. The Mishnah, in its present form, records sayings uttered as much as 400 years before its compilation while it is separated from ourselves by 1,700 years of copying. Thus we obtain our evidence only after it has been subjected to the hazards of oral and written transmission, the former often over long periods, the latter always so. These hazards have, in general, been met by a tradition of faithful repetition and copying; repetition was subject to the rule that 'one must quote a saying in the words of one's master' (Hayyav adam lomer bi-lshon rabbo), while the material copied was revered as authoritative from the time when it was first written down. The internal evidence from the Mishnah itself indicates that it contains substantially accurate transcriptions of the sayings recorded in it; the linguistic and stylistic grounds for this conclusion are discussed by Segal. ${ }^{10}$

The mother's recovery after caesarean section is implicit rather than explicit in the relevant passages, and some of the references to the operation could hardly 


\section{Feffrey Boss}

be late additions unless the text had been drastically reconstructed. No special claim to skill is made in mentioning the operation and the references to it cannot be read as such. If the text has been amended, the amendment is motiveless. It is of interest that in three of the passages, widely separated from each other, the well-known Rabbi Simeon is reported as taking a consistent attitude. The relevant passages occur in the oldest manuscripts. Furthermore, Maimonides, in the twelfth century, 400 years before what is usually supposed to be the first maternal recovery from caesarean section, discusses the operation as it is mentioned in the Mishnah, and his commentary on the Mishnah is known in an autograph Hebrew manuscript. ${ }^{20}$ We may therefore be sure that the Mishnah could not have been amended in this respect in view of advances in post-Renaissance surgery.

It thus appears that the Mishnaic references to caesarean section in a context implying the mother's recovery present fewer literary difficulties if they are considered as correct records of Tannaitic sayings than if they are supposed to be spurious. Even if they were spurious they would precede the development of the technique as it is known from other records.

It remains to be asked whether the implication that caesarean section was performed on living women is due to fantasy, and is merely an example of a 'thought experiment'. The comments of the Amoraim, teaching immediately after the period under consideration, make it obvious that they took the operation seriously, although it is possible that it was no longer performed in their time. On internal evidence it appears very unlikely indeed that the operation existed only in the Tannaitic imagination. Rabbinical teaching contained halachah and haggadah, the former being precepts of conduct and the latter including discussion of theology, ethical principles, history and other branches of learning; on haggadah speculation was common, but fantasy was never a feature of halachah, and the passages to be discussed in this paper are all halachic.

The following editions were used for this study. The Mishnah was read in Danby's translation, ${ }^{21}$ the relevant passages thus selected being examined in Blackman's pointed Hebrew text, ${ }^{22}$ which was checked against Lowe's transcription of the Cambridge manuscript; ${ }^{23}$ the discrepancies between Blackman's and Lowe's texts were found not to affect the substantial meaning of the passages to be discussed. Four passages of the Mishnah suggesting caesarean section with maternal recovery were found. Kassovsky's concordance of the Tosefta, ${ }^{24}$ s.v. ' 'Totsé dofan' indicates only passages without certain reference to an ante-mortem operation, and the Tosefta itself was not therefore consulted. The Mishnaic passages are themselves based on Exodus xiii and xxiv and Leviticus xii. The early rabbinical commentaries on these were consulted in Ugolini's Latin translation, ${ }^{25}$ but do not mention yotsé dofan. At the beginning of Sifra, the commentary on Leviticus, however, Rabbi Ishmael's rules of exegesis include a comment on Exodus xiii, 2, in which it is commanded to 'sanctify unto me all the first born, whatsoever openeth the womb among the children of Israel, both of man and of beast'. Rabbi Ishmael, who taught during the second 
quarter of the second century A.D., remarks: 'If it "openeth the womb" can I not suppose that it might come after a yotse dofan? But what is said is "firstborn".' This indicates the possibility of a pregnancy at some time after a caesarean section, although whether on a woman or a beast is not certain. As a similar passage of the Mishnah will be discussed more fully, no further comment is needed here.

The index of the Soncino translation of the Babylonian Talmud ${ }^{26}$ indicates no relevant baraitas. Through this index, however, a reference to ante-mortem caesarean section was found in the discussions of the Amoraim. This passage, with the four Mishnaic ones already mentioned are the subjects of the next five sections of this paper, one section being devoted to each. The numbering of passages of Mishnah and Gemara follows the usual conventions, the name of the tractate being followed by two numbers to indicate paragraphs of the Mishnah and corresponding Jerusalmi Gemara, or by a number and letter to indicate the folio in the Babylonian Talmud; the prefixes M., b. and j. indicate Mishnah and the Babylonian and Jerusalmi Talmuds respectively.

\section{Veterinary Practice}

The Mishnah (M. Bekhoroth ii, 9) states:

The yotse dofan and what comes after it: Rabbi Tarfon says, Both shall be pastured until they become ritually unsuitable and, being blemished, may be eaten by their owners. Rabbi Aqibha says, neither is a 'firstborn', the first because it does not 'open the womb' and the second because there is another before it.

Aqibha and Tarfon both taught in the period 120-135 A.D.; Aqibha's view on this matter is the accepted one. ${ }^{22}$ The relevant biblical passage is in Exodus xiii, I 2 and is repeated in different words in Exodus xxxiv, I9: 'Thou shalt set apart for the Lord all that open the womb, and each firstling.'

It is quite clear from these quotations that Tarfon and Aqibha were discussing the possibility of a beast born naturally by a dam who had previously undergone caesarean section. Animals born by caesarean section are frequently mentioned in the Talmud, but the passage quoted here is the only one I know which refers unequivocally to a subsequent birth by the same dam. The Amoraim continue the discussion whether the yotsé dofan or the subsequent normally born offspring is to be sacrificed as the firstborn (b. Bekhoroth $19 a-b),{ }^{26}$ and their remarks leave no doubt that they took seriously the possibility of a dam's recovery after the operation. Rashi (Rabbi Shelomo ben Yitzhaq of Sens, 1040-I 105 A.D.), in his commentary on the Talmud, ${ }^{27}$ makes the obvious point that the Mishnaic discussion is relevant only when the dam has borne no young before the yotsé dofan. Maimonides (Rabbi Mosheh ben Maimon, I I35-1204 A.D.), himself a physician, states in his commentary on the Mishnah ${ }^{10}$ that 'the flank is pierced and the foetus thus plucked out'. He continues, 'it is customary to do this even to women, if they have been in difficult labour and are at death's door'. If the Mishnah is to be interpreted according to its obvious meaning, the passage on which Maimonides is commenting raises technical 


\section{Jeffrey Boss}

problems not suggested by his comparison with the well-known rescue of an infant from a moribund mother, a rather different matter.

The commentaries on the Mishnah by Bartenora (Obadiah ben Abraham of Bertinoro, alive in $\left.{ }^{1488}\right)^{10}$ and Yom-Tov Lippmann Heller (published $\left.16 \mathrm{I}_{4}\right)^{28}$ give no additional information relevant to this study. The Tifereth Yisrael ${ }^{29}$ ('loveliness of Israel'), the commentary by Israel Lipschütz ( I 782-1860) on the Mishnah, defines two of the terms thus: "“yotsé dofan", what is cut out of its mother at the time of birth, the foetus being brought through the body-wall; "'and what comes after it", the subsequent birth through the normal passages'.

It therefore appears that the Mishnah implies the survival of the dam after caesarean section, and that the commentators have recorded no difficulty in accepting the evident meaning of the Mishnaic passage. They give no veterinary information, however, either to support or to controvert the possibility of recovery from the operation.

\section{Human Firstborn}

The Mishnah states (M. Bekhoroth viii, 2), 'Neither a yotsé dofan nor its successor is a "first-born" for either inheritance or the priest's money. Rabbi Simeon says, "The first for inheritance, the second for the five selaim".' The Gemara (b. Bekhoroth $47 \mathrm{~b}$ ) on this comments that

the first is not a first-born of inheritance because the condition required by Scripture is 'And they have born him' (Deut. xxi, I5). It is also not a first-born [as regards redemption] with five selas because the condition required [by Scripture] is: 'Openeth the womb' (Ex. xiii, 2). The second offspring is not a first-born of inheritance because the condition required [by Scripture] is: 'The first-fruits of his strength.'

Rashi merely comments that neither the yotse dofan nor what follows it is a firstborn, for reasons given in the Gemara.

At first sight there would seem little doubt that the mother of the child born by caesarean section must recover, since there is a subsequent birth. There is, however, another interpretation of the Mishnah, due to Maimonides, and accepted by Bartenora, Yom-Tov Lippmann Heller and Israel Lipschütz. Maimonides wrote:

It may happen that this woman is pregnant with double progeny, and one comes forth after the side of the belly is incised, and later the other comes forth by the ordinary route, and the first dies after the second comes out. But what some say, that a woman can live after her side is cut open and then bear a child, is contrary to reason and exceedingly absurd. The decision is not according to $\mathbf{R}$. Simeon.

Since Maimonides is the most outstanding interpreter of Jewish precept and custom since Roman times, and since he was a physician, it seems probable that this statement has been very influential in the interpretation of Talmudic sayings bearing upon caesarean section.

There are three reasons why it is difficult to accept the view taken by Maimonides. First, as Israels has pointed out, the word used here for 'its successor' 
(aharayv) occurs elsewhere in the Talmud in comparable contexts (Baba Bathra, M. I $9 a$ and $b$. I I Ib) where it clearly means one born by a later pregnancy. Secondly, in commenting on a passage of Mishnah (M. Niddah v, $\mathrm{I}$ ) discussed below, Maimonides assents without demur to the possibility of recovery from caesarean section. Finally, it seems rather unlikely that a recently incised uterus could expel an infant, especially if the mother is dead or at death's door, and it seems reasonable that once an incision had been made, both twins would have been delivered through it forthwith.

\section{The Post-partum Sacrifice}

According to Scripture (Lev. xii) a woman who has borne a boy offers a sacrifice after forty days, or after eighty days if the baby is a girl. The Mishnah (M. Kerithoth, i, 5) notes exceptions.

These bring nothing: she who aborts an amnion full of water, of blood or of bits, or who aborts what is like fishes, locusts, unclean and creeping things, or who bears through the belly wall. Rabbi Simeon makes liable in the case of what is borne through the belly wall.

It is evident that the difference between Rabbi Simeon and the others depends on the recognition by both sides that a woman is able to bring an offering forty or eighty days after caesarean section.

The Gemara (b. Kerithoth 7 b) comments thus:

What is the reason of $\mathbf{R}$. Simeon,-Said Resh Laqish: It is written, 'And if she bear a maidchild' (Lev. xii, 5) to include another kind of bearing, namely by means of a caesarean section. And what is the reason of the Rabbis?-Said R. Mani ben Pattish: It is written, 'If a woman conceive seed and bear' (Lev. xii, 2); only when the birth takes place through the seat of conception.'

The method by which the Mishnaic points of view are underpinned by biblical texts is outside the field of this paper, but it is clear that the Amoraim are capable of ingenuity in giving those explanations they think called for. Nevertheless, they make no comment on the implied survival of the mother after the operation, neither explaining away the implication of the Mishnah nor treating it as remarkable.

Rashi, in his commentary on the Talmud, does not discuss the mention of caesarean section in either Mishnah or Gemara. Maimonides takes up the theme of the Amoraim,

... The sages say 'if she bears', that is, only if she bears at the site of parturition. Rabbi Simeon backs his opinion by what is in the Torah (Lev. xii, 5) - 'and if a woman bear'-when it says 'and if' to include another kind of birth, namely the excision of the foetus from the belly; the decision is according to the Sages ...

Maimonides does not raise any objection to the material possibility of a postpartum sacrifice being offered by a woman who has undergone caesarean section, although he considers that no offering need be brought. Bartenora, 
Yom-Tov Lippmann Heller and Israel Lipschütz all follow the Gemara and Maimonides.

\section{The Days of Uncleanness}

Following the precepts in Leviticus (Ch. xii) a woman is unclean in the puerperium for seven days after the delivery of a boy and for fourteen days after that of a girl. The Tannaim said (M. Niddah iii, 4) that

she who aborts a sandal or shilya shall abide apart for both boy and girl (i.e. for a period as long as the two combined). A shilya in the house makes the house unclean, not because the shilya is the birth of young, but because there is no shilya without the birth of young. Rabbi Simeon says: The young could have dissipated before it (i.e. the shilya) came forth.

The term shilya, which occurs also in Deuteronomy (Ch. viii, 7), is explained by Hai ben Sherira Gaon (d. A.D. 1038) as the foetal membranes in the skein-like form in which they emerge. ${ }^{30} \mathrm{Krauss}^{31}$ defines sandal as, amongst other things, the name of a fish and of an abortion which is of the same shape. Maimonides states that it is 'in the form of a sandal or small ox tongue and forms in one pellicle with the embryo out of the residue of menstruum dripping on it'. Bartenora says that a sandal normally is born with the young, and in the Tifereth Yisrael it is described as 'young which has spoiled'.

For the present purpose the passage of Mishnah is interesting for the manner in which the Amoraim approached the difficulty raised. The difficulty is that there seems no point in mentioning the days of separation for a sandal or for membranes if a foetus always accompanies them. The expression 'for both boy and girl' suggests an uncertainty about the sex of an early abortion; a little further on the Mishnah (M. Niddah iii, 6) states that, for an abortion of indeterminable sex, the days for both boy and girl must be kept. Since the prescribed days are not to be kept for an abortion on or before the fortieth day of pregnancy (ibid., iii, 7), and since the Rabbis could determine the sex of an aborted foetus from the end of the fourth lunar month (b. Niddah $25 \mathrm{~b}$ ), 32 the passage of Mishnah given in the last paragraph may well refer to a period of gestation for much of which the membranes are much more conspicuous than the embryo. The sandal may be a plaque of clot from the site of separation.

The Amoraim (b. Niddah $26 \mathrm{a}$ and j. Niddah iii, $\mathbf{4}^{33}$ ) explain the Mishnah differently: 'The young emerges through the belly wall and the sandal by the natural route.' That this is a somewhat artificial explanation may have struck Rabbi Jose ben Rabbi Bun who, in the Palestine Gemara, comments (j. ibid.) 'A hole for the large is a hole for the small, but a hole for the small is not a hole for the large.' The possible artificiality of the explanation, which assumes postoperative survival during the days of uncleanness might make it of only slight relevance to the theme of this paper, were it not for Rashi's comment on the words 'the young emerges through the belly wall'. He notes: 'By sam.' The meaning of sam will be discussed below, but it certainly means something with which the operation was performed.

Here, then, is a curious situation. Rashi shows some knowledge of the means used for the operation, in a comment on a passage implying maternal survival, 
without demurring at that implication. Yet Maimonides, himself a physician, and living only a century later, considers it 'contrary to reason and exceedingly absurd' that a woman should heal and be able to bear again. Nevertheless, Rashi's sam is circumstantially convincing, especially in view of his more explicit comment, given in the next section of this paper. Might not a Rabbi of northern France have access to a tradition, no longer fully understood perhaps, which would not come to the notice of a sophisticated physician moving in the up-todate learned circles of the Moslem world?

The use of caesarean section as an explanation of this Mishnaic passage is not used in the commentaries on the Mishnah by Maimonides, Bartenora, Yom-Tov Lippmann Heller and Israel Lipschütz.

\section{The Days of Cleanness}

The period prescribed in the Pentateuch (Lev. xii) for the interval between a birth and the mother's offering is made up of seven days of uncleanness and thirty-three days of cleanness, or fourteen days and sixty-six for a girl. On this it was said,

what is delivered through the belly-wall: for this they do not keep the days of uncleanness and of cleanness, and for this they are not liable to a sacrifice. Rabbi Simeon says, such as this counts as a birth (M. Niddah v, $\mathrm{r}$ ).

Here it is seriously considered whether a woman ought to bring an offering forty or eighty days after the delivery of her child by caesarean section; Rabbi Simeon, in treating the operation as equivalent to a normal delivery, maintains the position he takes up elsewhere in the Mishnah.

The Amoraim (b. Niddah 4ra) do not demur at the implied survival after the operation, but expand the short statement into a longer discussion. Maimonides states,

Rabbi Simeon says: When the Pentateuch says, 'if she bear', it includes the foetus which comes forth from the side of the belly, that is, if the loins of the woman are parted because the foetus will not emerge, so that the embryo is delivered through the loins.

Maimonides considers Rabbi Simeon correct, and must therefore have thought him to have been talking sense in assuming the possibility of survival after caesarean section when interpreting a passage of scripture and, despite his previously quoted attack on the idea that a woman could recover and bear again after caesarean section, Maimonides does not here demur to her being well enough to make her purificatory offering.

Bartenora is explicit. On yotsé dofan in this passage of Mishnah he writes, 'If a foetus comes forth into the light through the side of its mother's belly, opened by means of certain medicaments, and if later she healed ...' Yom-Tov Lippmann Heller does not make this point, but the Tifereth Yisrael explains yotsé dofan as 'an infant which emerges by an opening in the belly wall', with the comment 'and she heals'. Now Bartenora and Israel Lipschütz follow the oldest complete commentary on the Mishnah, that of the eleventh-century Rashi who, as we have 


\section{Jeffrey Boss}

seen, remarked that caesarean section was performed by sam. Commenting on yotsé dofan in the passage now under consideration, he amplifies this point. 'By sam they opened the womb; they brought the foetus out, and she healed.'

\section{Summary of the Texts}

The texts quoted indicate that the Tannaim assumed that a woman could be fit to offer a sacrifice forty or eighty days after undergoing caesarean section, and that she might be delivered of an infant by a subsequent pregnancy. Internal evidence dates the texts to the second century A.D. and indicates that they were discussions of known possibilities and not of fantasies; the evidence of manuscripts shows that the texts must precede the development of the operation in Europe.

The three principal commentaries are the Gemara (completed in the fifth century A.D.) and those of Rashi (eleventh century A.D.) and Maimonides (twelfth century A.D.). The Gemara accepts the possibility of post-operative recovery, and mentions ante-mortem caesarean section by way of explanation of one passage of Mishnah which does not itself mention the operation. Maimonides considers healing and a subsequent pregnancy absurd, but he does not press this point for animals or for the post-partum sacrifice. In explaining the Mishnah so as to avoid admitting the possibility of maternal survival and a later birth, Maimonides formulates an alternative explanation which is textually and obstetrically weak. Rashi, on the other hand, seems to preserve a tradition of how the operation was performed.

The yotse dofan is mentioned in the Mishnah as a detail of more general discussions, and the mother's survival taken for granted. Ante-mortem caesarean section, saving both mother and child, seems therefore to have been accepted practice and not a fantastic exploit. This would explain why the Talmud never refers to any specific woman delivered in this way; such an example would not be the basis for a discussion, and it would be a matter of chance whether one was mentioned during comments on some other topic; in the event it was not. Nor is the technique described. As Israels points out, the Talmud gives detailed medical information on what is rare rather than what is common, and we do not suppose that a disease, for example, to which it refers (such as those in b. Gittin $69 \mathrm{ff}$.) must be unreal because its clinical details, being irrelevant to the subject in hand, are omitted.

That the operation and its outcome were taken for granted indicates that our texts do not refer to the occasional miracle of a mother's recovery after she had been taken for moribund or dead and the baby rescued from her womb. And if the mother was evidently alive her recovery must have been expected, or the operation would have been murder; the mother's life took precedence over that of the unborn foetus (M. Oholoth vii, 6).

\section{The Operation}

There is a baraita (b. Niddah 4ra) which reads: 'Our Rabbis taught: She who is in labour for three days and is delivered through the belly wall has given 
birth during a flow of semen.' Bartenora explains the last phrase to mean that the birth counted as one born through the site of a seminal reflux. It appears that the operation was indicated by a prolonged labour, one clear day being allowed to elapse between that on which the labour began and that of the operation.

We do not know what anaesthesia, if any, was used. None may have been needed. Pickrell ${ }^{3}$ quotes Sprengel on the first well-documented caesarean operation, performed in Germany in 1610 . Sprengel writes, 'The haemorrhage was not excessive, nor the pain great, as the patient herself stated afterwards'; no analgesic drug appears to have been used. On the other hand sleeping drugs, samme d'shinta, were available (b. Baba Metzia $83 \mathrm{~b})^{32}$ in Talmudic times.

As has been mentioned, the belly was, according to Rashi, opened by sam. We know three relevant things about sam: it was certainly not a cutting instrument, it was probably painless, and it was probably a kind of medicament. The evidence for these statements is presented by Israels, ${ }^{11}$ as follows. Rashi, in his commentary (b. Hullin 6gb) adds 'knife' to sam as a means of surgical opening. Elsewhere in the Talmud (b. Avodah Zarah 28b) it is written,

They treated ears on the Sabbath. R. Samuel b. R. Jehudah taught: by hand and not by sam. What is the reason of those who say by sam and not by hand? Because the latter makes incisions.

And again (b. Baba Kamma 85a), 'They think, how much does a man whose hand has been condemned by authority (i.e. the Gentile rulers under whom the Jews lived) consider whether it should be cut off by sam or by the sword?' On this last passage Rashi comments that sam might be preferable because it is painless. The precise meaning of sam cannot be ascertained, but Israels, in a footnote, discusses both the etymology and the use of the word; although he quotes a suggestion that, in one sense, it refers to the astringent Samian earth, it is commonly used for any drug, and no clue is given to its origin. Israels knows of no use of the word sam for an instrument.

The skill needed for such an operation implies some general tradition of surgery, and surgery was in fact considerably developed in Talmudic times among the Jews. ${ }^{32}$ From the Tannaitic period, the material on surgery is indicative but scanty, but among the Amoraim, who taught between roo and 300 years later than those Tannaim whose remarks on caesarean section have been discussed in this paper, there was considerable anatomical knowledge (b. Taanit $2 \mathrm{Ib}$ ), and surgical skill which encompassed veterinary hysterectomy (b. Bekhoroth $28 \mathrm{~b}$ ), as Israels points out.

From the technical point of view the exact meaning in this context of dofan 'body wall', is of the greatest interest. That Surenhusius ${ }^{10}$ (ca. I 700 A.D.) translated it by latus suggests a tradition that the side was opened, and Schapiro ${ }^{17}$ quotes a passage in support of this interpretation. 'And Abner struck in the fifth with the end of his sword' (2 Sam. ii, 23); Rabbi Johanan explained this to mean 'at the fifth dofan or space (counting from below up) where the liver and gall bladder are suspended' (b. Sanhedrin 49a). Schapiro is led by this to suspect that dofan means the right side. If it means either an intercostal space or rib, and 


\section{Feffrey Boss}

can also be used for the side as a whole, it is partially analogous in usage to the Latin costa. It seems most probable that dofan means 'parietes', but was used for the flank in particular.

This suggests that the operative approach was lateral, and might therefore have resembled the extraperitoneal techniques of Ritgen and Gaillard Thomas (Cf. Chassar Moir ${ }^{34}$ ). This would reduce the danger from sepsis, which would doubtless have been further lessened by a suitable dressing, such as is used in ritual circumcision. A lateral approach, if extraperitoneal, indicates considerable surgical sophistication. On the other hand, it is possible that the linea semilunaris was incised, as was done in Europe at the beginning of the eighteenth century. ${ }^{\circ}$

\section{Origin and Loss of the Skill}

The Old Testament does not mention caesarean section, either explicitly or implicitly, and it seems likely that the operation was developed or learnt in the half-millennium between the return from Exile and Bar-Cochbas's revolt. It is unlikely to have been learnt from the Romans, whose writings, while referring on several occasions to post-mortem section, never mention the ante-mortem operation. The Greek and Egyptian medical writings have no word on antemortem caesarean section. There seems to be only one Mesopotamian record of the operation: the hero Rustum is said to have been born magically by caesarean section while his mother was drugged with henbane. ${ }^{6,} 7$

That the technique was developed among the Jews themselves in Palestine or within their Mesopotamian communities is not in itself improbable. The prerequisites are ethical and technical. On the one hand the expectation of losing either the mother or the child must be felt as an intolerable dilemma: on the other, there must be existing knowledge and skill sufficient to enable a way of escape from the dilemma to be found. Both conditions are satisfied among the Jews of Palestine and Babylonia in the thousand years between the Exile and the spread of Islam.

The ethical position is seen when the status of the foetus is set down beside the alternative to caesarean section. The Tannaim said (M. Oholoth vii, 6):

The woman who was having difficulty in bearing - the foetus is cut up and withdrawn piece by piece, the parent's life (hayyah) taking precedence over the foetus's life (hayyah); but the greater part having emerged, it is not harmed, for a life (nefesh) does not take precedence over a life (nefesh).

Thus embryotomy of a living foetus was permissible because it was hayyah, but not yet nefesh. In the Gemara (b. Sanhedrin 9oa) ${ }^{35}$ the Amoraim discuss when the embryo receives its soul (nefesh), the possibilities from which to choose being conception and the time when the embryo is formed; Rabbi Samuel, who achieved a reputation for dating foetuses, considered the embryo to be formed completely at the end of the sixth week of pregnancy. The Amoraim would not have ignored the Tannaitic view, and it is therefore reasonable to conclude that a foetus in late pregnancy was considered nefesh in the Mishnaic Period. It is 
true that the embryo was considered a mere member of the mother, but only if its life was already lost or if its legal status as an unborn but independent person would otherwise have been implied. ${ }^{36}$ The saving of an existing foetal life was obligatory and caesarean section of a woman who had just died in pregnancy was carried out even on the Sabbath, in accordance with the rule that an action which may save life takes precedence over the Sabbath rest (b. Arakhin 7a). ${ }^{11,}{ }^{17}$ Embryotomy seems to have been an ethical pis aller, the implication that to become nefesh was determined by emergence being a justification contrary to the general view, and the motive must have been strong in seeking to avoid a choice between destroying one life, and allowing another to perish.

Some of the technical background is indicated by Spivak. ${ }^{32}$ There was a profession of surgeons (b. Sanhedrin 9Ib) who operated in protective tunics (M. Kelim xxvi, 5) and were familiar with minor procedures such as the freshening of wound edges to promote healing (b. Hullin 77) and the opening of abscesses (M. Eduyoth, ii, 5 44a). Veterinary hysterectomy has been mentioned. Anatomical knowledge was derived from autopsies (b. Niddah $35 \mathrm{~b}$ ), while physiological studies led to a realization that respiration was comparable with burning and that expired air cannot sustain life (b. Sanhedrin 88a), and it was appreciated that the movements of the body depend on the integrity of the spinal cord (b. Hullin 58). In gynaecology and obstetrics knowledge was extensive, 11,17 and special methods, such as the use of a vaginal speculum (b. Niddah 66) are mentioned in the Talmud. As already indicated, ante-mortem caesarean section was performed on beasts, and may have been developed first in veterinary practice; midwives attended domestic beasts as well as women (b. Hullin $43 a) .{ }^{37}$ There seems no reason why, given the ethical incentive, a technique for the human operation should not have been developed.

Disuse of the method would presumably have resulted from an increasing proportion of failures, probably maternal deaths. This may have been the result of defective transmission of the skill from master to learner, and this in its turn may imply that the operation was, towards the end, performed under very difficult conditions.

Now, in the early Middle Ages circumstances were such as might have driven caesarean section underground as a hole-and-corner procedure. Jewish communities were embedded in dominant Moslem or Christian majorities. As to the former, Young ${ }^{6}$ states that

Mohammedanism absolutely forbids it (caesarean section), and directs that any child so born must be slain forthwith, as it is the offspring of the Devil. In consequence of the influence of modern thought, this injunction is not strictly observed.

It would clearly have been dangerous for the Jews to have been known as the practitioners of such an unholy art, and the greatest centres of Jewish learning in Talmudic times later came under the rule of the Caliphate of Baghdad, when Islam was established from Spain to the Tigris and beyond. Might it not be that Maimonides' protestation that the operation was absurd was a device 


\section{Feffrey Boss}

to protect the Jews from the suspicion which the Mishnah would arouse among Moslems? In this way could be explained the weakness of Maimonides' argument and his failure to press it in more than one of the appropriate contexts; one explicit repudiation would have the required effect and could always be used by Jews when attacked on the matter.

Rashi, further north, did not consider the operation absurd, but his comments seem to imply that it was not performed in his time. In Christian Europe difficulties would have arisen not so much from explicit laws as from popular superstition. We know of no case even of post-mortem caesarean section among occidental Christians before 959 A.D., ${ }^{4}$ and to have delivered a child through the belly of a living mother who survived would surely have been to endanger oneself, in the second half-millennium A.D., as a presumed accomplice of the Devil or other agent of evil. If the operator was a Jew, his surgery could well have precipitated a bloody persecution at Christian hands.

It is not therefore to be wondered at if the Jewish tradition of caesarean section, driven underground in a Gentile world, should have been transmitted under conditions leading to a deterioration of technique. The resulting tendency to failure would have brought the operation into disrepute until, finally abandoned, it receded into the past, remembered but ill-understood.

\section{Summary}

In the second century of the Christian era the Jews practised caesarean section not only to rescue an infant from a dead mother, but also to rescue both mother and baby from a prolonged labour. The mother's survival is implicit in written passages which are unambiguous on the matter, serious in purpose, and certainly not the subjects of modern amendment.

The operation may have been learnt from another people, perhaps during the Exile, or have been developed by the Jews themselves during the time of the Second Temple, or soon after. The loss of the skill may have depended on Gentile attitudes in the early Middle Ages. On the origin and decline of the operation there is no direct evidence, but the hypotheses put forward here tally with the information available and provide a basis for discussion.

\section{ACKNOWLEDGMENTS}

It is a pleasure to thank Mr. F. M. Sutherland of the Wellcome Historical Medical Library for referring me to the writings of Schapiro ${ }^{17}$ and Ploss ${ }^{7}$, and Mr. A. E. S. Roberts and the staff of the Bristol University Medical Library for their patience in obtaining books from widely separated libraries.

\section{REFERENCES}

I. Justinian's Digesta, quoted by Fasbender, ${ }^{4}$ p. 27.

2. SkInNer, H. A. The Origin of Medical Terms. London, 1949 (s.v. 'Caesarean section').

3. Pickeel, Kenneth L. 'An Inquiry into the History of Cesarean Section'. Bull. Soc. Med. Hist. Chicago, iv, 414-53, 1935. 
4. Fasben De R, Hein rich. Geschichte der Geburtshülfe: Jena, 1906; pp. 979-1010.

5. Talmud (Arakhin 7a) in Israels ${ }^{11}$ and Schapiro' ${ }^{17}$.

6. Young, J. H. Caesarean section: the History and Development of the Operation from Earliest Times. London, 1944.

7. Ploss, H. H. and others. Woman. An Historical, Gynaecological and Anthropological Compendium; ed. E. J. Dingwall: London, 1935; pp. 86-7 and 91-4.

8. FELKIN, R. W. 'Notes on Labour in Central Africa.' Edin. Med. F., xxix, 922-30, 1884.

9. Davies, J. N. P. 'The Development of "Scientific" Medicine in the African Kingdom of Bunyoro-Kitara.' Med. Hist., III, 47-57, 1959.

10. Mishna ... cum . . . Maimonidis $\mathbb{E}$ Bartenorae-commentariis integris. Latinitate donavit . . G. Surenhusius. Amsterdam, 1698-1 703.

II. ISRAELS, A. H. Tentamen historico-medicum exhibens collectanea gynaecologica quae ex Talmude Babylonico depromsit A. H. Israels, Med. Doct. Groningen 1845. (Caput IV: De infante ex matris ventre exciso; pp. 160-84.)

12. MANSFE LD, cited by von Siebold ${ }^{15}$, Israels ${ }^{11}$, Ploss ${ }^{7}$ and Young ${ }^{6}$.

13. Crombie, A. C. Robert Grosseteste and the origins of experimental science, 1ro0-1700. Oxford, I953, p. 24 .

14. Fuld A, cited by Israels 11 and Ploss?.

15. Von Sie B old, C. J. Versuch einer Geschichte der Geburtshulfe. Berlin, i839-45.

16. Reich, B. 'Ueber einige Andeutungen des Kaiserschnitts an Lebenden nach dem Talmud.' Virchow's Archiv., xxxv, 365-8, 1866.

17. S cha piro, D. Obstétrique des Anciens Hébreux. Paris, 1904, pp. I53-62.

18. Neuburger, Max. History of Medicine (transl. E. Playfair), I. London, 1910 (from German edition of 1906).

19. Segal, M. H. A Grammar of Mishnaic Hebrew. Oxford, 1927, p. 9.

20. Maimonides. Commentarius in Mischnam e codicibus Hunt. 117 et Pococke 295 in Bibliotheca Bodleiana Oxoniensi servatis et 72-73 Bibliothecae Sassooniensis Letchworth; introductionem Hebraice et Britannice scripsit S. D. Sassoon, I (Corpus codicum Hebraicorum medii aevi, I). Copenhagen, 1956.

21. The Mishna, translated by H. Danby. Oxford, 1933 .

22. Mishnayoth. Translated, pointed and edited with notes by Philip Blackman. London, 1955 .

23. Lowe, W. H. Mishnah on which the Palestinian Talmud rests ... from the ... manuscript ... in the University Library of Cambridge. Add. 470, 1. Cambridge, 1883.

24. Haim JoshuA KAssovsky. Thesaurus Thosephtae. Jerusalem, 1932-.

25. Commentarius antiquissimus et eruditissimus in Leviticum, Numeros et in Deuteronomium. (Ugolini's Thesaurus antiquitatum sacrarum, Xrv.) Venice, 1752-3.

26. Talmud Babli, transl. into English. Ed. I. Epstein. London, 1935-48.

27. Talmud Babli. Lemberg, 1867.

28. Mischna ... cum commentariis Bertinora, fomtob Heller et recentiorum in his R. Akib Eiger. Ed. B. W. Eiger and N. A. Goldberg. Stettin and Berlin, $186 \mathrm{i}-2$.

29. Misznajoth $z$ dodanym nowym komentarzem. Tyfereth Israel przez Rabina F. Lipszytz napisanym. Warsaw, 1864.

30. Epstein, J. N. Der Gaonäische Kommentar zur Mischnaordnung Teharoth. Berlin, 1924.

31. KRAuss, S. Griechischer und lateinische Lehnwörter im Talmud, Midrasch und Targum. Berlin, 1898.

32. S pivax, G. D. in the Fewish Encyclopedia, New York and London, 1906 (s.v. 'Medicine').

33. Talmud Yerushalmi; Krotoshin, 5625 (1866).

34. MUnRo KerR's Operative Obstetrics: sixth edition by J. Chassar Moir. London, 1956.

35. Barton, G. A. in Encyclopedia of Religion and Ethics. Ed. J. Hastings. Edinburgh, 1920 (s.v. 'Soul (Semitic)').

36. Deмвітz, L. N. in the Jewish Encyclopedia (supra ${ }^{32}$ ), s.v. 'Embryo'.

37. Seligsonn M., in the Jewish Encyclopedia (supra ${ }^{32}$ ), s.v. 'Midwives'. 